\title{
Factibilidad financiera por opciones reales para la producción de Anturio (Anthurium andreanum Lindem Ex Andre) en Cuitláhuac, Veracruz*
}

\author{
Financial feasibility by real options for the Anthurium (Anthurium andreanum \\ Lindem Ex Andre) production in Cuitláhuac, Veracruz
}

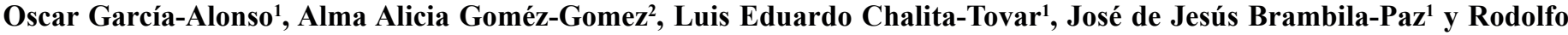 \\ García-Alonso $^{1 \S}$ \\ ${ }^{1}$ Colegiode Postgraduados-Campus Montecillo.Carretera México-Texcoco,km.36.5.Texcoco,Estadode México.Tel.5554056986,5546476279y7821296333.(almaaliciamx@ \\ yahoo.com; vieciel777@yahoo.com). ${ }^{2}$ Universidad Autónoma Chapingo-Departamento de Economía Agrícola. ${ }^{\S}$ Autor para correspondencia: rodoga@colpos.mx.
}

\section{Resumen}

Este trabajo se desarrolló por la inquietud de un grupo de mujeres del municipio de Cuitláhuac, Veracruz. El Colegio de Posgraduados en Ciencias Agrícolas, y sus estudiantes deben generar y difundir conocimiento para bien de la sociedad, por ello se realiza este trabajo, para poder determinar la factibilidad financiera del proyecto productivo denominado: Producción de anturio (Anthurium andreanum Lindem) en el municipio de Cuitláhuac, Veracruz. Con el objetivo evaluar el proyecto de inversión para la producción de anturio en la localidad en 2011, a través de la integración de las técnicas tradicionales de evaluación de proyectos y el enfoque de opciones reales. Se obtuvo un VAN (valor actual neto) de $\$ 132$ 986, relación beneficio- costo $(\mathrm{B} / \mathrm{C})$ de 1.07 , relación beneficio-inversión neta $(\mathrm{N} / \mathrm{K})$ de $1.274 \mathrm{y}$ tasa interna de retorno(TIR) de $17 \%$, por lo cual se llega a la conclusión de la factibilidad del proyecto. Al ser evaluado con la técnica de opciones reales bajo los escenarios de expansión, contracción, abandono y opción estratégica, se obtuvieron los siguientes valores: \$169209.26; \$147 894.73; \$145 798.53; \$184 038.33; respectivamente para cada una de los escenarios, por lo que se determina que los escenarios más importantes son el de opción estratégica y la opción de expansión.

Palabras clave: Anthurium andreanum, rentabilidad, proyectos, opciones reales.

* Recibido: febrero de 2014

Aceptado: marzo de 2014
This work was developed by the concerns of a group of women in the Cuitláhuac municipality, Veracruz. The Postgraduate College of Agricultural Sciences, and its students must generate and disseminate knowledge for the benefit of society, therefore this work is carried out in order to assess the financial feasibility of the production project entitled Anthurium (Anthurium andreanum Lindem) production in the Cuitláhuac municipality of Veracruz. In order to evaluate the investment project for the anthurium production in the municipality in 2011, through the integration of traditional techniques for project evaluation and a real options approach. ANPV (net present value) of $\$ 132$ 986, a benefit-cost ratio (B/C) of 1.07, net benefit-investment ratio $(\mathrm{N} / \mathrm{K})$ of 1.274 and internal rate of return (IRR) of $17 \%$ were obtained, which supports the project feasibility. When evaluated with the real options technique under scenarios of expansion, contraction, abandonment and strategic option, the following values were obtained: \$169 209.26; \$147 894.73; \$145 798.53; $\$ 184$ 038.33; respectively for each of the scenarios, therefore it is determined that the most important scenarios are the strategic and expansion options.

Keywords: Anthurium andreanum, profitability, projects, real options. 


\section{Introducción}

Lafloricultura en México ha crecido, gracias alaintroducción de nuevos cultivos, como el anturio, que siendo originario de Colombia (Baldewo et al., 2002) ha encontrado las condiciones ambientales adecuadas para su establecimiento en la zona centro del estado de Veracruz, esta ornamental tropical tiene una creciente demanda a nivel internacionaly un buen precio de compra por tallo floral, por sus atractivos colores (Kamemoto, 1988) y larga vida en florero (Islam, 2013). En México no se cuentan con estadísticas oficiales de la producción de anturio (SIAP, 2013); sin embargo, Murguia etal.(2000) indica que solo en el estado de Veracruz se tienen 10 hectáreas, repartidas en pequeñas unidades de producción en su mayoría familiares y de baja escala de tecnificación.

Los altos costos de malla sombra y plantas son los que han limitado la extensión del cultivo. La inversión de define como el acto de incurrir en un costo inmediato con la esperanza de obtener ganancias futuras (Dixit y Pindyck, 1994). Uno de los mayores problemas que se presenta al realizar el estudio y evaluación de proyectos, es justificar económicamente la inversión de recursos en un proyecto que se enfrenta a condiciones de alta volatilidad e incertidumbre (Garrido et al., 2010), ignorando que las condiciones cambian a través del tiempo (Domínguez, 2010).

Razón por la cual se requiere el planteamiento de proyectos que sean viables de ejecución, la evaluación tradicional presenta limitaciones al evaluar un proyecto solo bajo esta metodología. Existen técnicas alternativas que están directamente asociadas a la administración o gestión del proyecto (Bacchini, 2007). La teoría de opciones reales (Myers, 1977) permite al realizar la evaluación del proyectos y entregar una aproximación del valor de la flexibilidad que posee un proyecto, permitiendo al evaluador capturar numéricamente el valor de la estrategia (Trigeorgis, 1996; Garrido y Andalaft 2003). Una opción real está presente en un proyecto de inversión, cuando existe alguna posibilidad futura de actuación al conocerse la resolución de alguna incertidumbre actual (Amram y Kulatilaka, 2000).

Para determinar la viabilidad económica del establecimiento de una plantación de anturio en Cuitláhuac, Veracruz, se analizaron las diferencias que poseen las teorías tradicional y de opciones reales en su metodologías, haciendo uso del modelo binomial, el cual se basa en criterios simples que se derivan de la utilización de portafolios equivalentes y en

\section{Introduction}

Floriculture in Mexico has grown based on the introduction of new crops such as anthurium, which being originally from Colombia (Baldewo et al., 2002) has found suitable environmental conditions for its establishment in the central region of the state of Veracruz, this tropical ornamental crop has a growing international demand and a good purchase price per floral stem, by their attractive colors (Kamemoto, 1988) and long vase life (Islam, 2013). In Mexico no official statistics are available on anthurium production (SIAP, 2013), however, Murguia et al. (2000) indicate that there are 10 hectares in the state of Veracruz alone, spread into small production units mostly familiar and with low level of technification.

The high cost of mesh shade and plants have limited the crop extension. Investing is defined as the act of incurring in an immediate cost in the hope of obtaining future profits (Dixit and Pindyck, 1994). One of the biggest problems presented in project study and evaluation, is to economically justify the investment of resources in a project facing high volatility and uncertainty conditions (Garrido et al.,2010), ignoring that conditions change over time (Domínguez, 2010).

This is why viable project implementation is required the traditional assessment has limitations when evaluating a project solely under this methodology. There are alternative techniques that are directly related to project administration and management (Bacchini, 2007). The real options theory (Myers, 1977) enables project evaluation and give an approximation of the flexibility value of a project, allowing the evaluator to numerically capture the strategy value (Trigeorgis, 1996; Garrido and Andalaft 2003). Areal option is present in an investment project, when there is a future possibility of action after solving some current uncertainty (Amram and Kulatilaka, 2000).

In order to determine the economic viability of establishing an anthurium plantation in Cuitláhuac, Veracruz, methodological differences between traditional and real options theories were analyzed, using the binomial model, which is based on simple criteria derived from the use of equivalent portfolios and principles of behavior of arbitration models. Subsequently, the investment project was evaluated, were profitability indicators as NPV, B/C, $\mathrm{N} / \mathrm{K}$, IRR and sensitivity analysis were determined. Finally 
los principios de comportamiento de modelos de arbitraje. Posteriormente se evaluó el proyecto de inversión, en donde se determinaron los indicadores de rentabilidad como: VAN, B/C, N/K, TIR y el análisis de sensibilidad. Finalmente se evaluó el proyecto con las técnicas tradicionales y el enfoque de opciones reales, para identificar sus limitaciones y de esta manera obtener el valor real del proyecto de inversión tomando en cuenta el factor riesgo.

Acontinuación se citan los siguientes conceptos necesarios para la valoración de la opción:

Valor del activo subyacente: en este caso el activo subyacente es el proyecto por sí mismo, en donde el valor actual del proyecto es el valor presente del flujo de efectivo esperado de iniciar el proyecto ahora, el cual asciende a \$132 986(VAN).

Precio del ejercicio: este es el costo de expansión, el cual asciende a $\$ 520117.25$ y equivale al 100\% de la inversión del proyecto, es decir, equivale a establecer otra unidad de producción.

Varianza en el valor del activo: los factores con alta volatilidad, ocasionan que exista incertidumbre en las estimaciones de los flujos de efectivo y por ende en el valor presente del valor del activo subyacente. Para este proyecto, se consideró al precio del anturio como el factor de mayor riesgo.

Fecha de expiración de la opción: el periodo durante el cual la opción es viable; siendo de 10 años y podría ejercerse en cualquier momento durante el mismo.

Tasa libre de riesgo: esta es la tasa de interés anual libre de riesgo y se calcula como sigue:

$\frac{1+C E T E S}{1+\left(\pi^{e}\right)^{2}}=1+r$

CETES: es la tasa de interés que pagan los certificados de la tesorería, $\pi^{e}$ : es la inflación esperada. r: es la tasa de interés real. Los Cetes a 28 días del día 21 de junio de 2011 ascendían a 4.35 y la inflación esperada era igual a 3.5. Con éstos datos, la tasa libre de riesgo se calcula como sigue: $1.0435 / 1.001225=1+\mathrm{r} ; \mathrm{r}=4.22 \%$

Se tienen que calcular los valores de las variables $u, d$, pyq. the project was evaluated using traditional techniques and the real options approach to identify its limitations and thus obtain the real value of the investment project taking into account the risk factor.

Then the following concepts for option valuation are listed below:

Value of the underlying asset: in this case the underlying asset is the project itself, where the present value of the project is the present value of expected cash flow to start the project now, which amounts to $\$ 132986$ (NPV).

Exercise price: this is the cost of expansion, which amounts to $\$ 520117.25$ and equals $100 \%$ of the investment project, i.e. equivalent to setting another production unit.

Variance in the assets value: factors with high volatility, cause uncertainty in estimates of cash flows and therefore in the present value of the underlying asset value. For this project, the anthurium price was considered as the major risk factor.

Expiration date of the option: the period during which the option is viable, being 10 years and may be exercised at any time during the year.

Risk-free rate: this is the annual risk-free rate and is calculated as follows:

$\frac{1+C E T E S}{1+\left(\pi^{e}\right)^{2}}=1+r$

CETES: is the interest rate paid by treasury certificates, $\pi^{e}$ : is the expected inflation $\mathrm{r}$ : is the real interest rate. CETES after 28 days from the day June $21^{\text {st }}, 2011$ amounted to 4.35 and expected inflation was equal to 3.5 . With these data, the risk-free rate is calculated as follow: 1.0435/1.001225 $=1+\mathrm{r}$; $\mathrm{r}=4.22 \%$

The values of the $u, d, p$ and $q$ variables must be calculated.

$U=$ is the coefficient of increase in the value of the underlying asset and is calculated as follows:

$U=e^{\sigma \sqrt{\delta . t}}=e^{0.42438639 \sqrt{1}}=1.528652136$

$d=$ is the coefficient of decrease in the value of the underlying asset, i.e., measures the amplitude of the asset variation. 
$U=$ es el coeficiente de ascenso del valor del activo subyacente y se calcula como sigue:

$U=e^{\sigma \sqrt{\delta . t}}=e^{0.42438639 \sqrt{1}}=1.528652136$

$d=$ es el coeficiente de descenso del valor del activo subyacente; es decir, mide la amplitud de la variación de dicho activo.

$d=e^{\sigma \sqrt{\delta . t}}=e^{-0.42438639 \sqrt{I}}=0.6541710679$

$p=$ es la probabilidad del riesgo neutral, su cálculo es el siguiente.

$p=\frac{e^{(r f f(\delta . t)}-d}{u-d}=\frac{e^{(0.0422)(1)}-0.6541710679}{1.528652136-0.6541710679}=\frac{0.38893201}{0.8744810681}=0.4447574971$

$q=(1-p)=1-0.4447574971=0.555242502$

Para poder calcular la probabilidad de que ocurra cada resultado del último año, y posteriormente obtener el valor esperado del proyecto de ese último año, se requiere utilizar la siguiente fórmula:

$p=\left[\frac{T !}{(T-n) ! n !}\right] *\left[p^{n}(1-p)^{T-n}\right]$

En la que $\mathrm{T}=10 ; \mathrm{n}=10,9,8,7,6,5,4,3,2,1$ (es el número del nodo, iniciando por el nodo de arriba).

$p=0.579474366 ; 1-p=0.420525633$.

\section{Evaluación del proyecto: opción de expansión}

Ante este escenario se pretende una ampliación de 100\% en la producción de anturio. El valor actual de la inversión que es de \$132 986.04 (valor del activo subyacente) puede ascender en un año hasta tomar el valor de \$203 289.39, si todo va bien. Si las expectativas no se cumplen dicho valor podría descender hasta $\$ 86995.62$. La probabilidad de que todo vaya bien es $\mathrm{p}_{\mathrm{u}}=0.444757497$. De esta manera se van realizando los cálculos hasta llegar al periodo 10.

Con base en elárbol binomial del valor del proyecto (Figura 1a), se procede a realzar el cálculo de la opción de expansión. Éste cálculo se realiza en dos pasos, el primero es el cálculo de los nodos terminales y el segundo es el cálculo de los nodos intermedios hasta llegar al nodo inicial que tiene un valor de \$169 209.26 (Figura 1 b).

El primer paso es calcular el valor de expansión de los nodos terminales, el cual es equivalente a incrementar la capacidad existente $100 \%$, menos los costos de expansión. Un ejemplo del cálculo del valor de expansión de un nodo $d=e^{\sigma \sqrt{\delta . t}}=e^{-0.42438639 \sqrt{\pi}}=0.6541710679$

$p=$ is the risk neutral probability, the calculation is as follows.

$p=\frac{e^{(r)(\delta)(. t)}-d}{u-d}=\frac{e^{(0.0422)(1)}-0.6541710679}{1.528652136-0.6541710679}=\frac{0.38893201}{0.8744810681}=0.4447574971$

$q=(1-p)=1-0.4447574971=0.555242502$

To calculate the probability of each outcome occurring last year, and then obtain the expected value of the project last year, the following formula is required:

$p=\left[\frac{T !}{(T-n) ! n !}\right] *\left[p^{n}(1-p)^{T-n}\right]$

Where: $\mathrm{T}=10 ; \mathrm{n}=10,9,8,7,6,5,4,3,2,1$ (it is the node number, starting with the top node).

$p=0.579474366 ; 1-p=0.420525633$.

\section{Project evaluation: expansion option}

Given this scenario, a 100\% expansion is intended for anthurium production. The current value of the investment is $\$ 132986.04$ (underlying asset value) may rise up to $\$ 203$ 289.39 after a year, if all goes well. If expectations are not met that value could fall to $\$ 86995.62$. The probability that all is well is $p_{u}=0.444757497$. In this way the calculations are performed up to the 10 period.

Based on the binomial tree of the project value (Figure 1a), we proceed to enhance the calculation of the expansion option. This calculation is performed in two steps, the first is the calculation of the terminal nodes and the second is the calculation of the intermediate nodes to reach the initial node having a value of \$ 169209.26 (Figure $1 \mathrm{~b}$ ).

The first step is to calculate the expansion value of the terminal nodes, which is equivalent to increasing $100 \%$ the existing capacity less the expansion costs. An example of calculating the expansion value of a terminal node would be the AAD node, which has a value of \$ 18011 900.59 which are obtained from maximizing the value of the expansion option, which is: [2(9 266008.92$)-520$ $117.25]=\$ 18011900.59$, versus continue unchanged for the AAD node. In this manner all the expansion values of the terminal nodes are obtained where in some cases the option that maximizes the node value (profits), is to continue with existing operations only. 
terminal sería el nodo AAD, el cual tiene un valor de $\$ 18011$ 900.59 los cuales se obtienen de la maximización del valor de la opción de expansión, que es: [2(9 266 008.92) - 520 $117.25]=\$ 18011900.59$; versus continuar sin cambios para el nodo AAD. De esta manera se obtienen todos los valores de expansión de los nodos terminales, en donde en algunos casos la opción que maximiza el valor del nodo (ganancias), es el de continuar sólo con las operaciones existentes.
The AT node has a value of \$ 11624484.91 , at this point there are two options, expand operations or keep the expansion option open for the future, with the hope that market conditions will improve, and the company will have the opportunity to exercise the option and thereby increase its operations in $100 \%$. In this node the expansion value is $[2(6061554.95)-520117.25]=\$ 11602992.65$; however, the value of continuing with the open option

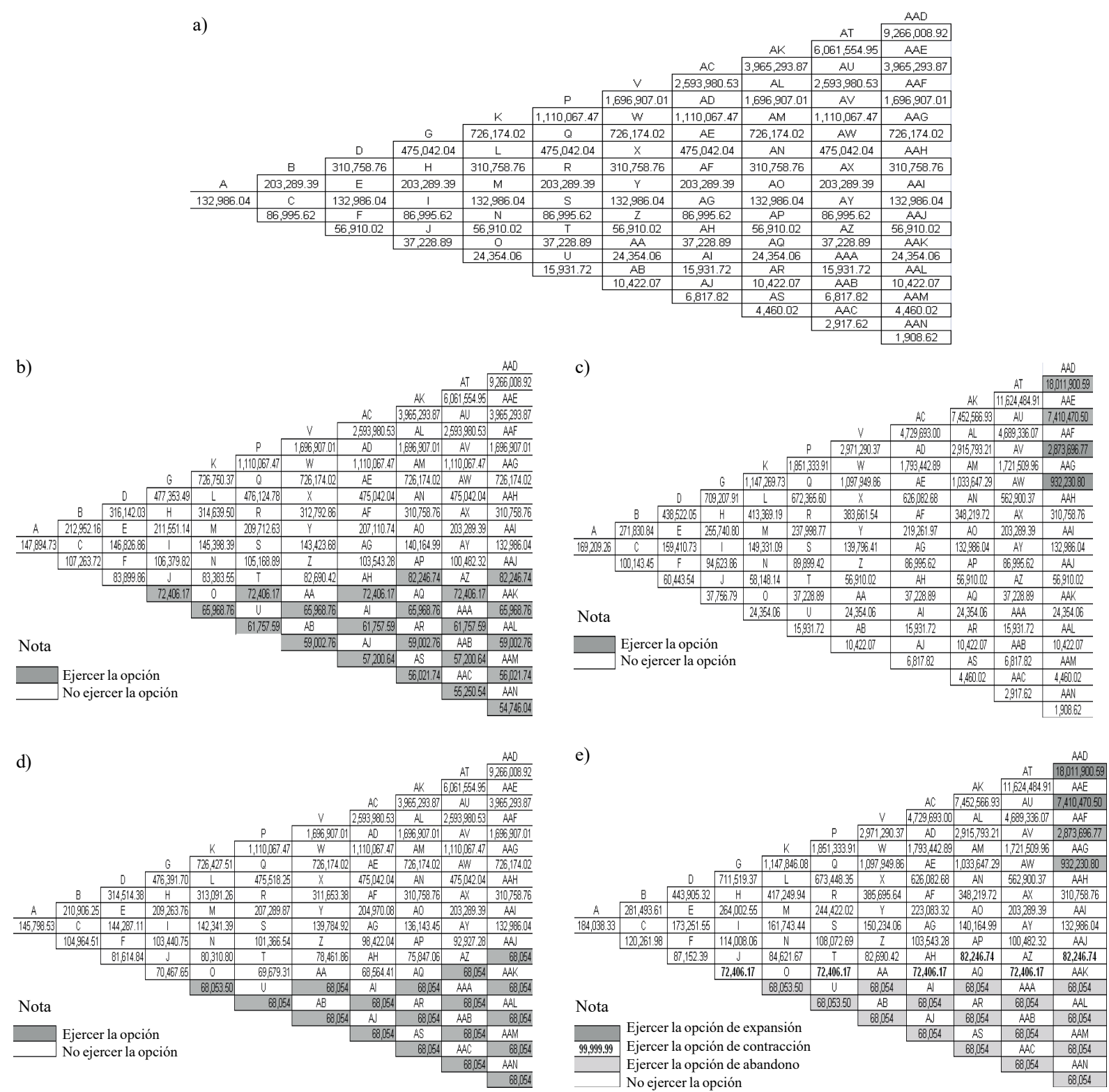

Figura 1. Construcción del árbol binomial según los datos generados por el proyecto: a) en general y para las opciones de; b) expansión; c) contracción; d) abandono; y e) estratégica, elaboración con datos propios.

Figure 1. Construction of the binomial tree on the data generated by the project: a) overall and for the options of; b) expansion; c) contraction; d) abandonment; and e) strategic, elaboration with own data. 
En el nodo AT se tiene un valor de $\$ 11624484.91$, en este punto se tiene dos opciones, expandir las operaciones o mantener la opción de expansión abierta para el futuro, con la esperanza de que las condiciones de mercado mejoren, así la empresa tendrá la oportunidad de ejercer la opción y con ello incrementar sus operaciones en $100 \%$. En este nodo el valor de expansión es [2(6 061 554.95)- 520 117.25] = $\$ 11602$ 992.65; sin embargo, el valor de continuar con la opción abierta es [p (18011 900.59) +(1-p)(7 410 470.50)* $\left[e^{(-r f)(\delta . t)}\right]=\$ 11624484.91$; el cual es más alto que el valor de expansión. Mediante la técnica de inducción regresiva el valor del nodo inicial es calculado en \$169 209.26; el cual representa elVPN, y la diferencia entre este y el valor obtenido por medio del flujo de caja descontado es el valor de la opción de expansión, el cual para este caso es de: \$36 223.23.

\section{Evaluación del proyecto: opción de contracción}

El único argumento que cambia es el precio de ejercicio, el cual asciende ahora a $\$ 53791.73$, los cuales representan $50 \%$ de los costos variables totales del proyecto, dado que se piensa contraer $50 \%$ de las operaciones. Primeramente se calculan los nodos terminales eligiendo la opción que maximice las ganancias del proyecto. En el nodo terminal AAD se tiene un valor de $\$ 9266008.92$ los cuales se obtienen de la maximización del valor de la opción de continuar sólo con las operaciones existentes, contrario a ejercer la opción de contracción, ya que si la empresa decide contraer sus operaciones, el resultado sería de [(0.5) (9266 008.92) + $53791.73=\$ 4686796.19$ para el nodo ADD, el cual es menor que la opción de continuar sólo con las operaciones existentes. En el nodo terminal AAJ se tiene un valor que se obtiene de la maximización del valor de la opción de contracción, que es $[(0.5)(56,910.02)+53791.73]=\$ 82$ 246.74; versus continuar sin cambios para el nodo AAJ, por lo que la opción que maximiza ganancias es la de contraer las operaciones de la empresa.

El segundo paso en el cálculo del valor de la opción de contracción es calcular los nodos intermedios, por ejemplo, en el nodo intermedio AT se tiene un valor de \$6061554.95. En éste punto la empresa tiene dos opciones a elegir, contraer las operaciones o mantener la opción de contracción y con ello minimizar sus pérdidas. Realizando estos cálculos hacia atrás hasta llegar al nodo inicial se obtiene un valor que asciende a $\$ 147894.73$; la diferencia que existe entre este valor y el valor obtenido a través del flujo de caja descontado (\$132 986.04) que es de \$14 908.69; es el valor de la opción de contracción. is $[p(18011900.59)+(1-p)(7410470.50) *=\$ 11624$ 484.91; which is higher than the expansion value. Through the backward induction technique the value of the initial node is estimated at \$169209.26, which represents the $\mathrm{NPV}$, and the difference between this and the value obtained using the discounted cash flow is the value of the expansion option, which for this event is: \$36223.23.

\section{Project evaluation: contraction option}

The only argument that changes is the exercise price, which now stands at $\$ 53791.73$, representing $50 \%$ of total variable costs of the project, since it is thought to contract $50 \%$ of operations. First, terminal nodes are calculated choosing the option that maximizes the project profits. The terminal AAD node has a value of $\$ 9266008.92$ obtained from maximizing the option value to continue only the existing operations, contrary to exercise the contraction option, because if the company decides to contract operations, the result would be $[(0.5)(9266008.92)+53791.73=\$ 4686$ 796.19 for the ADD node, which is less than the option of continuing with existing operations only. In the terminal AAJ node there is a value obtained by maximizing the value of the contraction option, which is $[(0.5)(56,910.02)$ $+53791.73]=\$ 82246.74$, versus continue unchanged for the AAJ node, thus the option for maximizing profits is to contract the company's operations.

The second step in calculating the value of the contraction option is calculate intermediate nodes, for example, the AT intermediate node has a value of $\$ 6061554.95$. At this point the company has two options to choose from, contract the operations or keep the contraction option thereby minimizing losses. Performing these calculations backwards to the starting node, a value of $\$ 147894.73$ is obtained, the difference between this value and the value obtained through the discounted cash flow $(\$$ 132 986.04) which is $\$ 14908.69$, is the value of the contraction option.

\section{Project evaluation: abandonment option}

The only argument that changes is the exercise price, which now stands at \$ 68054 (representing the salvage or rescue value of the project). In the abandonment option, the exercise price is the liquidation value of the project and for this specific project will be the salvage value of fixed investment, which may be recovered in case the project value falls below the liquidation value, which is $\$ 68054$. 


\section{Evaluación del proyecto: opción de abandono}

El único argumento que cambia es el precio de ejercicio, el cual asciende ahora a $\$ 68054$ (los cuales representan el valor de salvamento o de rescate del proyecto). En la opción de abandono el precio de ejercicio es el valor de liquidación del proyecto y para este proyecto específico será el valor del salvamento de la inversión fija, el cual se podrá recuperar en caso que el valor del proyecto disminuya por debajo del valor de liquidación, el cual es de $\$ 68054$.

En la Figura 1c, al término de los 10 años, la empresa tiene la opción de abandonar o continuar con el proyecto, el valor de continuar se puede ver en los nodos, AAD, AAE, AAF, AAG,AAHy AAI, en donde la decisión de maximización de ganancias indica continuar. El valor de abandono se presenta en los nodos AAJ,AAK, AAL, AAM y AAN, dado que están por debajo del valor de salvamento: \$68 054 .

El segundo paso en el cálculo del valor de la opción de abandono es calcular los nodos intermedios, por ejemplo, en el nodo intermedio AT se tiene un valor de $\$ 6061554.95$, que es mayor al valor de salvamento, por lo tanto en este nodo lo acertado es optar por la opción de continuar.

\section{Evaluación del proyecto: opción estratégica}

Otra opción que pudiese ser valiosa para este proyecto de producción de anturio es la opción estratégica, en donde la empresatiene la opción de: a)expandirlas operaciones actuales en $100 \%$, lo cual implicaría un costo de implementación que asciende a $\$ 520117.25$; b) contraer las operaciones en $50 \%$, lo que implicaría ahorros adicionales por $\$ 53791.73$; c) abandonar completamente las operaciones en algún momento dentro de los próximos 10 años, lo que implicaría recuperar el valor de salvamento de $\$ 68054$; y d) continuar sin cambios, para el cálculo del valor de esta opción se utilizan casi los mismos argumentos que en la opción de expansión, contracción y abandono, en donde el único argumento que cambia es el precio de ejercicio, que ahora será elegido entre las diferentes opciones antes enumeradas.

Para obtener el nuevo valor del proyecto (VAN expandido) y el valor de la opción estratégica con el enfoque de opciones reales, se utilizará el método binomial con el valor del proyecto (Figura 1a) y se procede a calcular el valor de la opción estratégica, para la cual se observa que el
In Figure 1c, after 10 years, the company has the option to abandon or continue the project the value of continuing can be seen in the AAD, AAE, AAF, AAG, AAH and AAI nodes, where the profit-maximizing decision indicates continuing. The abandonment value occurs in the AAJ, AAK, AAL, AAM and AAN nodes, since they are below the salvage value: $\$ 68054$.

The second step in calculating the value of the abandonment option is to calculate the intermediate nodes, for example, in the AT intermediate node there is a value of $\$ 6061554.95$, higher than the salvage value, therefore in this node the right choice is to continue.

\section{Project evaluation: strategic option}

Another option that could be valuable for this project of anthurium production is the strategic option, where the company has the choice of : a) expand current operations in $100 \%$, with an implementation cost of $\$ 520117.25$; b) contracting operations by $50 \%$, meaning additional savings of $\$ 53791.73$; c) completely abandon operations sometime within the next 10 years, which would recover the salvage value of \$ 68 054; and d) continue without changes, the calculation of value for this option uses almost the same arguments as in the expansion, contraction and abandonment options, where the only argument that changes is the exercise price, which will now be selected from the options enumerated above.

In order to obtain the new project value (expanded NPV) and the value of the strategic option with the real options approach, the binomial method is used with the project value (Figure 1a) and proceed to calculate the value of strategic option for which it is noted that the AAD terminal node has a value of $\$ 18011900.59$, obtained from maximizing the expansion, contraction, abandonment and continue unchanged options. At the end of the 10 years, the company has the option to choose how to continue through these operations. In the AAD node the expansion value is [2(9 266008.92$)-520,117.25]$ $=\$ 18011900.59$; the contraction value is $[(0.5)(9266$ $008.92)+53791.73]=\$ 4686796.19$; the value of the abandonment option is \$ 68054 and finally the value of continuing existing operations is $\$ 9266008.92$. Therefore the decision that maximizes profits is to expand operations in the AAD node. 
nodo terminalAAD tiene unvalor de $\$ 18011900.59$; los cuales se obtienen de la maximización de las opciones de expansión, contracción, abandono y continuar sin cambios. Al término de los 10 años, la empresa tiene la opción de elegir como quiere que continúen sus operaciones a través de esas operaciones. En el nodo AAD se tiene que el valor de expansión es de [2(9266 008.92) -520,117.25] $=\$ 18011900.59$; el valor de contracción es de $[(0.5)(9266008.92)+53791.73]=\$ 4686796.19 ;$ el valor de la opción de abandono es de $\$ 68054$ y por último, el valor de continuar con las operaciones existentes es de $\$ 9$ 266008.92 . Por lo tanto la decisión que maximiza ganancias es expandir las operaciones en el nodo AAD.

El valor de la opción estratégica no es igual a la suma de las opciones individuales, la razón que explica esta situación es que una empresa jamás puede contraer sus operaciones y expandirlas al mismo tiempo en el mismo nodo, por otro lado, en éste proyectoy en particular la opción de contracción excluye a la opción de abandono, por lo que con la opción estratégica y utilizando el método binomial se puede capturar la interacción de los diferentes tipos de operaciones.

El establecimiento de una plantación de anturio en Cuitláhuac, Veracruz, se justifica al ser un cultivo tropical (Baldewo et al., 2002) y por las condiciones de la localidad, se puede tener una producción a lo largo del año y con buena calidad lo que garantizara tener un buen precio en el mercado (Kamemoto, 1988), al realizar la valoración económica se ha demostrado que este proyecto es viable y que garantiza tener opción en la ejecución y que se puede expandir, contraer o abandonar cuando así sea necesario según los intereses de los integrantes de la empresa (Garrido, et al. 2010), con lo que estarían garantizando su inversión y obtener ganancias a largo plazo (Dixit y Pindyck, 1994). La utilización de la metodología de opciones reales permite tener un análisis y evaluación del proyecto de inversión, el cual muestra diferencias significativas entre la magnitud del VAN siny conflexibilidad.

\section{Conclusiones}

A raíz de los indicadores obtenidos con la evaluación tradicional, el proyecto de anturios es financieramente viable y rentable para su establecimiento en Cuitláhuac, Veracruz; sin embargo, esta metodología asume que es un proyecto de inversión de oportunidad; es decir, no es capaz de incorporar la incertidumbre ni la flexibilidad gerencial en la toma de decisiones.
The value of the strategic option is not equal to the sum of the individual options, the reason for this is that a company can never contract and expand its operations at the same time on the same node, on the other hand, in this project and particularly the contraction option excludes the abandonment option, thus with the strategic option and using the binomial method the interaction of the different operation types can be captured.

The establishment of an anthurium plantation in Cuitláhuac, Veracruz, is justified by being a tropical crop (Baldewo et al., 2002) and by the local conditions, good quality production is feasible throughout the year which guarantees a good market price (Kamemoto, 1988), the economic assessment has shown that the project is viable and guarantees options in the implementation and can be expanded, contracted or abandoned as needed according to the interests of the company members (Garrido et al., 2010), which would be ensuring the investment and obtaining long-term profits (Dixit and Pindyck, 1994). The real options methodology enables the analysis and evaluation of the investment project, which shows significant differences in NPV with and without flexibility.

\section{Conclusions}

Following indicators obtained with traditional evaluation, the anthurium project is financially viable and profitable for establishment in Cuitláhuac, Veracruz, however, this methodology assumes an investment opportunity project, i.e., unable to incorporate either uncertainty or managerial flexibility in decision-making.

The company has the option to expand operations in $100 \%$, thus increasing NPV from \$132 986.04 to \$169 209.26, where the difference is the value of the expansion option. Conversely, contracting operations by $50 \%$, would change the NPV from \$132 986.04 to \$147 894.73, where the difference is the value of the contraction option. The option of completely abandoning operations is available if market conditions make the project unprofitable, then the NPV would increase from $\$ 132986.04$ to $\$ 145798.53$ where the difference represents the value of the abandonment option.

End of the English version

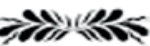


La empresa tiene opción de expandir sus operaciones en $100 \%$, con ello su VAN se incrementaría de \$132 986.04 a $\$ 169$ 209.26, en donde la diferencia representa el valor de la opción de expansión. Por el contrario Si se decidiera contraer sus operaciones en 50\%, su VAN pasaría de $\$ 132$ 986.04 a $\$ 147894.73$, en donde la diferencia representa el valor de la opción de contracción. Se tiene la opción de abandonar las operaciones totalmente si las condiciones de mercado provocan que el proyecto deje de ser rentable, con ello su VAN se incrementaría de \$132 986.04 a \$145 798.53 , donde la diferencia representa el valor de la opción de abandono.

\section{Literatura citada}

Amram, N. y Kulatilaka, N. 2000. Opciones reales: evaluación de inversiones en un mundo incierto. Gestión 2000. Barcelona, España. 311 p.

Bacchini, D. 2007. Valuación de un proyecto de inversión utilizando Opciones Reales. Centro de Investigación en Métodos Cuantitativos aplicados a la Economía y la Gestión. Facultad de Ciencias Económicas. Argentina. 3-12 p.
Buldewo, S. and Jaufeerally, F. F. 2002. Isolation of clean and PCR ampliafiable DNA fron Anthurium andreanum. Plant Mol. Biol. Reporter 20:71.

Dixit, A. K. and Pindyck, R. S. 1995. Investment under uncertainty. PrincetonUniversity Press, Princeton, $468 \mathrm{pp}$.

Domínguez,A. R. 2010. Valores críticos para evaluar proyectos agrícolas en escenarios de precios estocásticos. Rev. Fitotec. Mex. 33(1)79-83.

Garrido, C. I. A. 2010. Evaluación económica de proyectos de inversión basada en la teoría de opciones reales. Universidad de Concepción de Chile. 83-89 pp.

Garrido, C. I. A. y Andalaft, C. A. 2003. Evaluacion económica de proyectos de inversión basada en la teoría de opciones reales. Rev. Ing. Indus. 2:83-90.

Islam, M. S.; Mehraj, H.; Ronim, Z. K.; Sahrin, S. and Jamal, A. F. M. 2013. Varietal study of Anthurium (Anthurium andreanum) as a cut flower in bangladesh. J. Bangladesh Academy Sci. 37(1):103-107.

Murguía-González, J. Riestra-Díaz, D.; Gallardo-López, F.; AlonsoLópez,A.; Olguín-Palacios, C.; Cruz-Castillo, J.G.; RodríguezLagunes; D. A. y Flores-Murguía, A. 2003. Caracterización de factores socioeconómicos del cultivo de anturio (Anthurium andreanum Linden) en el estado de Veracruz, México. Revista Chapingo Serie Horticultura. 9(1):163-177.

Myers, S. C. 1977. Determinants of corporate borrowing. J. Financial Econ. 5:147-175.

Trigeorgis, L. 1996. Real Options. Managerial flexibility and strategy in resource allocation. MIT Press, Cambridge, E.U. 427 p. 